\title{
Description of the Health Status of Colombian Indigenous Communities Through Basic Laboratory
}

\section{Tests}

\author{
Martha Castillo, Ana Lucia Oliveros and Ana Isabel Mora \\ Faculty of Health Sciences, Universidad Colegio Mayor de Cundinamarca, Calle 28 No. 5B-02, Bogotá, D.C. 110911, Colombia
}

Received: March 15, 2014 / Accepted: September 28, 2014 / Published: September 30, 2014.

\begin{abstract}
Colombia enjoys considerable ethnic diversity, although its indigenous population, part of the world's shared cultural heritage has been reduced by various factors, including displacement, poverty, and poor access to timely and quality healthcare. The present study is focused on diagnosing health problems, particularly anemia, through a description of hematological findings amongst men and woman aged 18 to 50 years, living at various altitudes, and belonging to several different indigenous communities: the Huitoto and Embera of Caqueta, Florencia; the Bora, Muinane, Okaina, Huitoto communities of La Chorrera, Amazonas; and the Yanaconas of Bogota, D.C. Tests performed included automated hemogram tests, ferritin, c-reactive protein, and parasitological assessment to correlate the presence of anemia and parasitism. The authors used a quantitative and transversal, structured, non-experimental, correlational, stratified sample design with 105 samples (51 men, 54 women). The results showed that 7.8\% (4/51) of the men had anemia, compared with $29.6 \%(16 / 54)$ of the women-more than triple the incidence of the male population. Moreover, we found a higher incidence of anemia in rural areas, where the majority of the country's indigenous populations live. In the parasitological study, $87.7 \%$ (50/57) of the participants tested positive for intestinal parasites. These findings are expected to help authorities implement more effective responses to health issues in these communities.
\end{abstract}

Key words: Embera, Bora, Muinane, Huitoto, Okaina, native Americans, anemia, intestinal parasitism.

\section{Introduction}

Over the years, the size of Colombia's indigenous populations has decreased significantly, owing to multiple bio-psychosocial and socio-demographic factors, including low coverage within the health system, and loss of geographical territory. There is insufficient documentary evidence regarding the statistics and indicators of health in these communities [1-4].

Multiple pathologies suffered by indigenous peoples are often diagnosed and treated within the communities by community authorities (for example, shamans) using traditional techniques, an approach that sometimes hinders the use of medicine provided by the national health system [5].

Corresponding author: Martha Castillo, professor, research fields: health sciences, hematology. E-mail: mlcastillo@unicolmayor.edu.co.
The National Epidemiological documentation [1] highlights significant morbidity and mortality within these minority groups. This, and the fact that many Colombians have some degree of genetic descent from indigenous populations, calls for more epidemiological study of these populations. The present study sought to detect different pathologies in certain regions with significant indigenous populations with the objective of enhancing the development of more specific interventions and protocols that could be implemented by government agencies. This is especially important in the areas of hematology, and also in generating primary care programs that reduce the nutritional deficiencies and polyparasitism affecting these highly marginalized groups, who often live in suboptimal health conditions, far from urban centers and representative indices of 
morbidity and mortality [6-10].

\section{Materials and Methods}

The sample corresponds to participants who meet the inclusion criteria: men and women over 18 years of age from the Huitoto and Embera indigenous communities in the city of Florencia, Caquetá; the Bora, Muinane, Okaina, and Uitoto communities in the district of La Chorrera, Amazonas; and the Yanaconas of Bogota, D.C. Plans for the project were initially presented to community council leaders, and coordination was performed with the communities participating in the study, informing them of the relevance of the research, and the conditions that must be met for the collection of samples. All participants were volunteers who signed statements of their informed consent.

A total of 105 serum and whole blood samples from members of Colombian indigenous communities, as well as 57 stool samples from indigenous communities' participants in Florencia, Caquetá (45) and Amazonas (12) were analyzed. Automated hemogram tests were performed on the blood samples, with corresponding morphological tests for hemoparasites, ferritin, C-reactive protein, and parasites in stool samples. All variables were converted to proportions using SPSS 17.0. All numeric variables were categorized according to clinical criteria.

\section{Results and Analysis}

The study involved the councils and members of the indigenous Huitoto and Embera communities of
Florencia, Caquetá, and the Bora, Muinane, and Okaina Huitoto communities in the district of $\mathrm{La}$ Chorrera, Amazonas, and the Yanaconas of Bogota, D.C.

105 samples were collected, of which 51 (48.6\%) were from men and 54 (51.4\%) were from women.

For populations living at higher elevations above sea level, hemoglobin levels were lower than in populations living at lower altitudes, as shown in Table 1. It was observed that in general women had less hemoglobin than men.

It is found that $19 \%(20 / 105)$ of the participants had anemia. The highest incidence was observed in the community of Amazonas, where $28 \%$ of the total had anemia: $63 \%(5 / 8)$ of women and $14 \%(3 / 21)$ of men. The next highest incidence of anemia, $22 \%$ was found in Caquetá: 31\% (11/36) women and 5\% (1/19) of men. No anemia was observed in the sample from Bogotá, as shown in Table 2.

With respect to ferritin values, as shown in table 3, amongst men, $3.8 \%$ had values above the normal range, $15.4 \%$ had low values, and $80.8 \%$ were normal; amongst women, $1.9 \%$ had values above the biological range reference, $17.0 \%$ had low values, and the remaining $81.1 \%$ were normal.

Low ferritin levels do not prove to be a good indicator of anemia. Low levels of ferritin are considered to be below $20(\mathrm{ng} / \mathrm{mL})$; subjects are considered to be anemic for values of hemoglobin below $13 \mathrm{~g} / \mathrm{dL}$ in men, and below $12 \mathrm{~g} / \mathrm{dL}$ in women; observe the numbers of men with low ferritin who are not anemic, and the numbers of anemic women with normal ferritin.

Table 1 Haemoglobin level in men and women by altitude (meters above sea level).

\begin{tabular}{lll}
\hline Altitude $(\mathrm{m})$ & Sex & Hemoglobin $(\mathrm{g} / \mathrm{dL})$ \\
\hline 2600 (Bogotá) & $\mathrm{F}$ & 15.8 \\
2600 (Bogotá) & $\mathrm{M}$ & 17.9 \\
250 (Amazonas) & $\mathrm{F}$ & 12.0 \\
250 (Amazonas) & $\mathrm{M}$ & 14.4 \\
370 (Caquetá) & $\mathrm{F}$ & 11.7 \\
370 (Caquetá) & $\mathrm{M}$ & 14.4 \\
\hline
\end{tabular}


Table 2 Percentage of anaemia in indigenous communities.

\begin{tabular}{lllll}
\hline Location & Sex & Anemia & Total sampled & Percentage with anemia \\
\hline Bogotá & $\mathrm{M}$ & 0 & 11 & $0 \%$ \\
& $\mathrm{~F}$ & 0 & 10 & $0 \%$ \\
\multirow{3}{*}{ Caquetá } & Total & 0 & 21 & $0 \%$ \\
& $\mathrm{M}$ & 1 & 19 & $5 \%$ \\
& $\mathrm{~F}$ & 11 & 36 & $31 \%$ \\
Amazonas & Total & 12 & 55 & $22 \%$ \\
& $\mathrm{M}$ & 3 & 21 & $14 \%$ \\
& $\mathrm{~F}$ & 5 & 8 & $63 \%$ \\
Total & Total & 8 & 29 & $28 \%$ \\
\hline
\end{tabular}

Table 3 Percentage of ferritin.

\begin{tabular}{llll}
\hline Sex & Low & Normal & High \\
\hline Men & $15.4 \%$ & $80.8 \%$ & $3.8 \%$ \\
Women & $17.0 \%$ & $81.1 \%$ & $1.9 \%$ \\
\hline
\end{tabular}

Table 4 Percentage of stool samples testing positive for intestinal parasites.

\begin{tabular}{lll}
\hline Stool sample & Positive & Negative \\
\hline Population & 50 & 7 \\
\hline
\end{tabular}

With respect to C-reactive protein all the test were normal had values the normal range $>0.05 \mathrm{mg} / \mathrm{L}$.

In total, 57 stool samples were collected. In the Amazonas community, 11 of the 12 collected were positive for intestinal parasites (91.7\%), including Blastocystis sp. histolyticalEntamoeba dispar, Giardia intestinalis, Ascaris lumbricoides and Trichuris trichiu. Of the 45 collected in the community of Caquetá, $86.7 \%$ were positive for intestinal parasites. Overall, $87.7 \%(50 / 57)$ of the samples collected were positive for intestinal parasites as shown in Table 4 .

\section{Discussion}

Although there have been numerous studies on various aspects of indigenous peoples in Colombia, there has not yet been a comprehensive study to determine the current states of health among the different groups. The present study provides a significant contribution that is expected to support the design of health policies concerning medical intervention, disease prevention, and promotion of good health to address problems in these communities.
It has been noted [7] that the prevalence of parasites causing high rates of morbidity and mortality in isolated communities is due to a combination of the climatic situation, deficient sanitation, unhealthy lifestyle practices, and lack of knowledge about the transmission of parasites and infection.

Indigenous communities in Bogotà and Caquetà live in the outskirts of the city and do not have pipelines to supply them with safe drinking water. Communities living in remote Amazon jungle areas also have water supplies of dubious provenance, usually no kind of health security, and overcrowded living conditions. As a result, sanitary conditions in all these communities tend to be poor, favoring parasitism and malnutrition [8]. Previous studies [8] have found Blastocystis $s p$. histolytica/Entamoeba dispar, Giardia intestinalis, Ascaris lumbricoides and Trichuris trichiu.

Decreased hemoglobin values were found in $19 \%$ (20/105) of the participants, indicating states of anemia in the study population in line with the values set by the World Health Organisation (WHO). Ranges 
of the population are within established biological values, but tending to lower limits considering the height above sea level in the communities of Amazonas and Caquetá. Higher hemoglobin values have been observed in Bogota and communities located at 2,600 $\mathrm{m}$ above sea level, because of hypoxia.

The highest incidence of anemia was observed in communities of Amazonas, followed by communities of Caquetá; no anemia is present in the community of Bogotá. This is due to the socio-demographic factors in the regions, such as relative poverty and malnutrition.

Some $16 \%$ of the sample exhibited low ferritin levels, and while anemia is also present, there is no strong linkage between low ferritin and anemia, suggesting that the cause of anemia is not iron deficiency, or alternatively that ferritin levels may be influenced by infections or malnutrition, making it an unreliable indicator of iron deficiency. However, with respect to C-reactive protein, all the tests were normal, with values in the normal range $>0.05 \mathrm{mg} / \mathrm{L}$, suggesting that the normal ferritin levels were not influenced by infections or inflammation but by malnutrition, and that they probably have insufficient iron.

In the present study, it was difficult to obtain a large number of volunteers because of tendencies amongst the indigenous communities to keep to their traditional medicines and beliefs.

\section{Conclusions}

Colombian indigenous communities in Amazonas and Caquetá analyzed in the study exhibit deficiencies in health status, and a high presence of intestinal parasites and anemia in some individuals was observed. The Bogotá indigenous communities were found to be healthy. It is concluded that these problems are likely related to the lack of hygiene, suboptimal sanitary conditions, and poor diets suffered by the communities living in the remote
Amazon and Caquetá jungles.

Incidence of anemia, especially among women, was high in Amazonas and Caquetá. Ferritin levels in these populations were also observed to be generally within WHO established biological reference ranges, which would normally suggest adequate levels of iron. However, elevated ferritin levels can be associated with inflammatory infections or malnutrition, meaning that the ferritin level may not be a reliable indicator of iron deficiency.

Although the sample size of women from the communities of Amazonas is small, the incidence of iron deficiency anemia found in this population should be studied in greater depth.

It would recommend that health coverage for indigenous communities be reconsidered, as it is important to create a system that meets their needs while at the same time taking into account, for socio-cultural reasons, traditional medicinal practices.

This study represents an important advance for the health science community, providing new knowledge that could positively influence the development of good health practices that would help improve the quality of life within vulnerable communities.

\section{References}

[1] Instituto Nacional de Salud, Boletín Epidemiológico Nacional 2009 [National Epidemiological Bulletin 2009]. 2010. Bogotá: INS.

[2] Navarro Wolff, A., and, Goméz Hurtado, A. 1991. "Goméz Hurtado Constitución Política de Colombia [Political Constitution of Colombia]." Art 7.

[3] Cordone, A., and Brizzi, A. 2011. Los Pueblos Indigenas: Valorar, Respetar y Apoyar La Diversidad [The Indigenous Peoples: Valuing, Respecting, and Supporting Diversity]. Rome: FIDA.

[4] Vargas, L. A., Campos Navarro, R., and Casillas, L. E. 2010. "La Atención a Los Pacientes en Los Servicios de Salud Para Poblaciones Indígenas [Attention to Patients in Health Services for Indigenous Populations]." Boletin Mexicano de Historia y Filosofia de la Medicina 13: 21-26.

[5] Vargas Trejos, D. L., and Bañol Alvarez, N. D. 2010. “Análisis de la Percepción y el Grado de Satisfacción en la Relación Medico Paciente de la Atención en Medicina 
Tradicional: Resguardo Indígena de San Lorenzo, Riosucio, Caldas, 2008 [Analysis of the Perception and Degree of Satisfaction in the Doctor-patient Attention Relationship in Traditional Medicine: Indian Reservation of San Lorenzo, Riosucio, Caldas, 2008]." dissertation, Universidad CES.

[6] World Health Organization 2007. La Salud de Los Pueblos Indigenas [The Health of Indigenous Peoples]. Geneva: WHO.

[7] Núñez L., F., Zarante, I. M., and Bernal V., J. E. 2002. "Estado de Salud Infantil en Las Comunidades Indígenas, Afrocolombianas y Aisladas en Colombia [State of Infant Health in Indigenous, Afro-Colombian, and Isolated Communities in Colombia]." Medicina 24: 27-42.

[8] Puerta, L., Salazar, L., Velásquez, L., Vélez, I. D. 2011. "Estado Actual de Las Parasitosis Intestinales en Cuatro
Comunidades Indígenas de Colombia [Current State of Intestinal Parasitosis in Four Indigenous Communities of Colombia]." Biomédica 31: 98-99.

[9] Montilla, M., Soto, H., Parra, E., Torres, M., Carrillo, P., and Lugo, L., et al. 2011. "Infestation by Triatomine Bugs in Indigenous Communities of Valledupar." Colombia, Revista de Saúde Pública 45: 773-780.

[10] Parra Henao, G., Angulo, V., Jaramillo, N., Restrepo, M. 2009. "Triatominos (Hemiptera: Rediviidae) de la Sierra Nevada de Santa Marta, Colombia: Aspectos Epidemiológicos, Entomológicos y de Distribución [Triatomines (Hemiptera: Reduviidae) of the Sierra Nevada of Santa Marta, Colombia: Epidemiological, Entomological, and Distributional Aspects]." CES Medicina 23: 17-26. 